\title{
A Case of 17 Years Old Male with Short Stature and Delayed Adolescence due to Distorted Body Image
}

\author{
Yumiko Kinoshita1, Zenro Kizaki², Kensuke Matsuo', Yasunori Ishihara', \\ Shinsuke Adachi ${ }^{1}$, Kitaro Kosaka ${ }^{1}$, Akihiko Kinugasa ${ }^{1}$ and Tohru Sugimoto ${ }^{1}$ \\ ${ }^{1}$ Department of Pediatrics, Kyoto Prefectural University of Medicine, Kyoto, \\ ${ }^{2}$ Kyoto First Red Cross Hospital, Kyoto, Japan
}

\begin{abstract}
We report a $17 \mathrm{yr}$ old male with short stature and delayed adolescence due to distorted body image. He was admitted to our hospital because of growth failure at the age of $15 \mathrm{yr} 7 \mathrm{mo}$. His growth had been normal, but after entering a junior high school, he began to take an interest in physical exercise and protein diet. His endocrine data and psychopathological profiles such as eating, training pattern and extreme diet and failure to make expected growth and puberty were compatible with DSM-IV and ICD-10 criteria for the diagnosis of anorexia nervosa (AN). The symptoms of male AN are different from female AN and it is difficult to diagnose. We emphasize the necessity of considering AN in the differential diagnosis of growth retardation and delayed adolescence in young males.
\end{abstract}

Key words: short stature, delayed adolescence, adolescent male, anorexia nervosa

Introduction

Anorexia nervosa (AN) is an illness characterized by a distorted attitude toward eating, food, body weight and significant selfinduced weight loss by diet, vomitting, or laxative abuse. It is less prevalent in males than females but approximately $10 \%$ of AN patients are male $(1,2)$. It is difficult to identify male patients due to the lack of specific symptoms such as amenorrhea in a female $(2,3)$. We report a 17 yr old male who was admitted to our hospital because of growth failure and delayed adolescence due to distorted body image.

Correspondence: Dr. Yumiko Kinoshita, Department of Pediatrics, Kyoto Prefectural University of Medicine, Kyoto 602-8566, Japan

E-mail: kinoshi@kyoto.kpu-m.ac.jp

\section{Case Report}

A 15 yr 7 mo old male was referred to our clinic for growth failure. His growth had been normal, but after entering junior high school, he began to take an interest in physical exercise and protein diet. At that time his growth velocity decreased to $0.8 \mathrm{~cm} / \mathrm{y}$ (Fig. 1). On admission, his height was $149.3 \mathrm{~cm}(-3.2 \mathrm{SD})$ and his body weight was $40.5 \mathrm{~kg}$ (-1.8 SD); obesity index was $-6.9 \%$. Tanner stages of external genitalia and pubic hair were degree I. Bone age was 13 yr 8 mo, which was two years delayed compared to his chronological age. Blood examination was done and the results are shown in Table 1. Peripheral blood cell count was normal. Serum ALP and BUN were $490 \mathrm{IU} / \mathrm{l}$ and $21.7 \mathrm{mg} / \mathrm{dl}$, respectively. Serum testosterone and IGF-1 concentrations were $29 \mathrm{pg} / \mathrm{ml}$ and $183 \mathrm{ng} / \mathrm{ml}$, respectively. Peak GH values with L-dopa, 


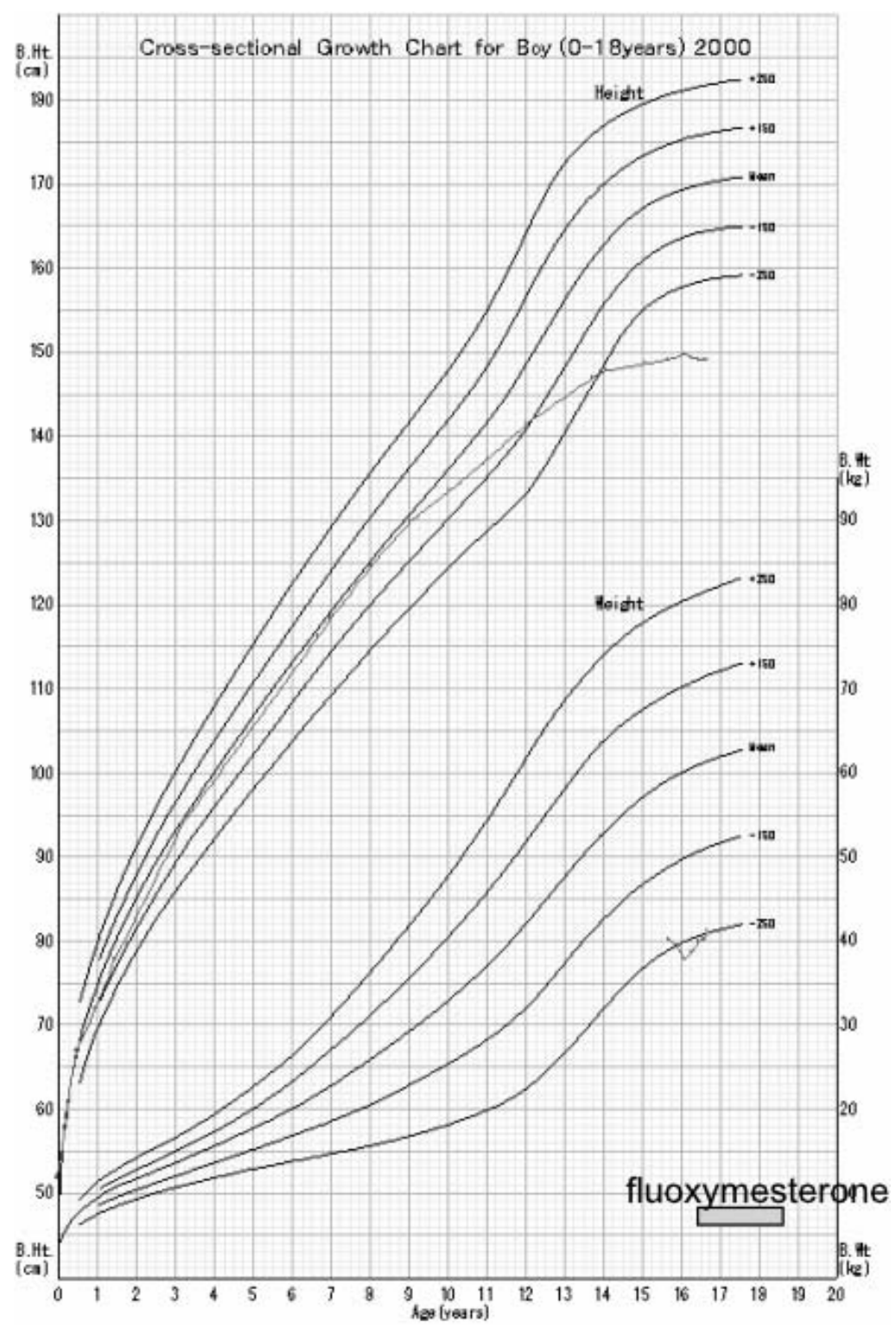

Fig. 1 Clinical course (Growth chart): Height velocity had been decreasing since the patient was $10 \mathrm{yr}$ old.

glucagons and arginine loading were $15.5 \mathrm{ng} / \mathrm{ml}$, $24.3 \mathrm{ng} / \mathrm{ml}$ and $21.1 \mathrm{ng} / \mathrm{ml}$, respectively. Basal serum concentrations of $\mathrm{LH}(<10 \mathrm{mIU} / \mathrm{l})$ and FSH $(<10 \mathrm{mIU} / \mathrm{l})$ were low, and the LH-RH test showed a prepubertal peak level and delayed response (Fig. 2). The level of TSH was normal, but the level of FT3 was slightly decreased. MRI study detected no intracranial lesion. In follow up, we began to suspect his growth failure and hypogonadism were probably due to AN, because the peripheral blood data and psychopathological profiles such as training, eating pattern and extreme diet, never telling us his body weight before coming to our clinic, and failure to make expected growth and puberty were compatible with DSM-IV and ICD-10 criteria for the diagnosis of $\operatorname{AN}(3,4)$. He continued 
Table 1 Laboratory data

\begin{tabular}{llll}
\hline WBC & $4,000 / \mu \mathrm{l}$ & $\mathrm{Na}$ & $140 \mathrm{mmol} / \mathrm{l}$ \\
$\mathrm{Hb}$ & $13.9 \mathrm{~g} / \mathrm{dl}$ & $\mathrm{K}$ & $4.9 \mathrm{mmol} / \mathrm{l}$ \\
$\mathrm{Plts}$ & $36.2 \times 10^{4} / \mu \mathrm{l}$ & $\mathrm{Cl}$ & $103 \mathrm{mmol} / \mathrm{l}$ \\
$\mathrm{LDH}$ & $317 \mathrm{IU} / \mathrm{l}$ & FT3 & $2.76 \mathrm{pg} / \mathrm{ml}$ \\
$\mathrm{ALT}$ & $32 \mathrm{IU} / \mathrm{l}$ & FT4 & $1.19 \mathrm{ng} / \mathrm{ml}$ \\
$\mathrm{AST}$ & $31 \mathrm{IU} / \mathrm{l}$ & TSH & $0.463 \mu \mathrm{IU} / \mathrm{l}$ \\
$\mathrm{ALP}$ & $490 \mathrm{IU} / \mathrm{l}$ & IGF- & $183 \mathrm{ng} / \mathrm{ml}$ \\
$\mathrm{BUN}$ & $21.7 \mathrm{mg} / \mathrm{dl}$ & LH & $0.5 \mathrm{mIU} / \mathrm{ml}$ \\
$\mathrm{Cre}$ & $0.49 \mathrm{mg} / \mathrm{dl}$ & FSH & $3.4 \mathrm{mIU} / \mathrm{ml}$ \\
TP & $7.1 \mathrm{~g} / \mathrm{dl}$ & testosterone & $7.3 \mathrm{ng} / \mathrm{dl}$ \\
Alb & $4.5 \mathrm{~g} / \mathrm{dl}$ & Urine $\mathrm{GH}$ & $34.3 \mathrm{pg} / \mathrm{mg} . \mathrm{Cr}$ \\
\hline
\end{tabular}

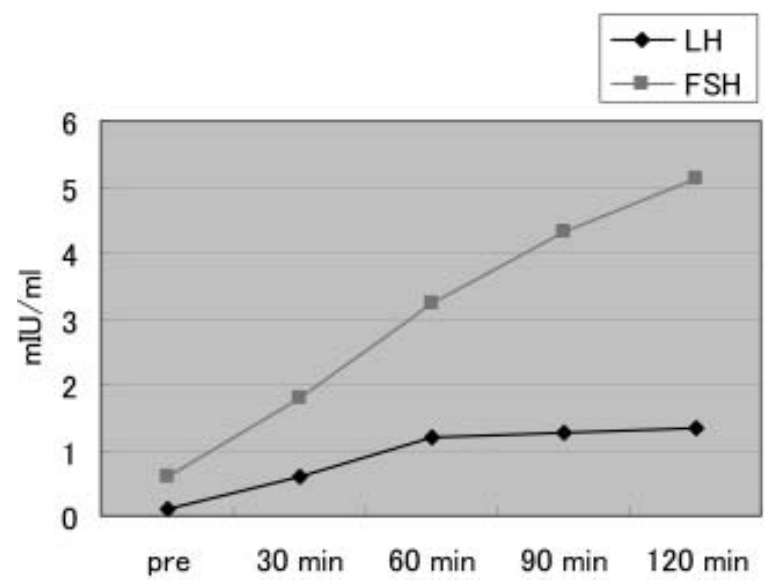

Fig. 2 LH-RH test: Delayed response of LH-RH showed hypothalamic hypogonadism.

the unbalanced protein diet and excessive exercise for a year, only to show $2 \mathrm{~kg}$ weight loss at the age of 16 yr 0 mo (obesity index and BMI were -16.8\% and 17.1, respectively). We advised him to change his daily life, and started fluoxymesterone to improve his delayed adolescence. After 6 mo, his weight returned to $40 \mathrm{~kg}$, but there was no improvement in height and delayed adolescence. At that time the level of ALP, IGF-I and testosterone were $145 \mathrm{IU} / \mathrm{l}, 66 \mathrm{ng} / \mathrm{ml}$ and $8.2 \mathrm{ng} / \mathrm{dl}$, respectively, and the peripheral blood cell count showed anemia. Now the patient is $17 \mathrm{yr}$ old, and there has been no improvement in his height.

\section{Discussion}

Sporadic cases of male AN have been described $(2,5)$. Male AN is difficult to identify because of its lack of symptoms such as amenorrhea in females. Body images are different with sex: females wish for a smaller and leaner body and try to lose weight by diet, while males desire a more muscular physique as well as thinness and try to gain weight, but sometimes lose weight through exercise. The features of male AN are 1. Excessive or compulsive physical activity and exercise are seen consistently; 2. Males are less likely to consider themselves at risk of AN and may be embarrassed by the prospect of having a female disease, thus less likely to seek treatment; 3. Families, social networks, and health care providers are less likely to consider AN in a male; and 4. Diagnoses may be more difficult to establish, leading to further delays in intervention (6).

We present the case of a $17 \mathrm{yr}$ old male with short stature and delayed adolescence due to distorted body image. He desired a more muscular physique, so he did excessive exercise and maintained a strict protein diet. His laboratory data showed hypothyrodism, hypothalamic hypogonadism, a normal level of GH secretion and low IGF-1. They are significantly associated with AN in males. We thought the reasons he showed short stature were that his psychopathological 
profiles were noticed too late, and consequently advice to change them was given too late. We guess he carried out the diet and exercise for a long time. We emphasize the necessity of considering anorexia nervosa in the differential diagnosis of growth retardation in young male adolescents.

\section{References}

1. Feighner JP, Robins E, Guze SB. Diagnostic criteria for use in psychiatric research. Arch Gen Psychiatry 1972;26:57-63.

2. Root AW, Powers PS. Anorexia nervosa presenting as growth retardation in adolescents. J Adolesc Health Care 1983;4(1):25-30.

3. Diagnostic and statistical manual of mental disorders (DSM-IV), 4th edition. American Psychiatric Association; 1980. P. 67-9.

4. International statistical classification of disease and related health problems, 10th revision. World Health Organization Genova.

5. Kulig JW, Siqueira LM. Diagnosis of anorexia nervosa in the adolescent male. J Adolesc Health Care 1983;4(1):31-4.

6. Rose DS. Eating disorders in adolescent males. Adolesc Med 2003;14(3):677-89. 